\title{
SPECTRORADIOMETRY OF COMMERCIAL WOOD VENEERS IN THE VISIBLE AND NEAR INFRARED SPECTRA
}

\author{
Diogo Belmonte Lippert ${ }^{1}$, Ana Caroline Paim Benedetti ${ }^{2}$, Matheus Mesquita da Costa Nunes ${ }^{3}$, Lucas \\ Alexandre Kervald ${ }^{3}$, Mateus Sabadi Schuh ${ }^{3}$, Rudiney Soares Pereira ${ }^{4}$ \\ ${ }^{1}$ Forest Eng., M.Sc. UFSM, Santa Maria, RS, Brasil - diogolippert@gmail.com \\ ${ }^{2}$ Forest Eng., Dr., UFSM, Santa Maria, RS, Brasil - anacaroline@ politecnico.ufsm.br \\ ${ }^{3}$ Academics of Forest Engineering Graduation Course, UFSM, Santa Maria, RS, Brasil - lucaskervald@ hotmail.com; \\ matheusnunes_florestal@hotmail.com; mateuschuh@hotmail.com \\ ${ }^{4}$ Forest Eng., Dr., UFSM, Santa Maria, RS, Brasil - rudiney@ smail.ufsm.br
}

Received for publication: 16/07/2012 - Accepted for publication: 22/10/2013

\begin{abstract}
This study aimed to analyze the spectral response in ten commercial wood veneers from ten forest species, in the visible and near-infrared regions of the electromagnetic spectrum. Reflectance of samples was obtained using a Field Spec®3 spectroradiometer. Results were verified through the analysis of variance followed by a Tukey range test on multiple means, which showed significant differences in both the analyzed spectral regions for the studied species. The most expressive differences were observed in the visible region and occurred between the "tauari" and "nogueira" wood veneers. Those results may be due to the chemical properties of the analyzed material, to the cellulose content, to the proportion of the components in the cell wall and to the extractives in the lumen, to microfibril angle, density and to resistance and stiffness properties. Therefore, the applied technique was a tool capable to identify reflectance variations in regions of the electromagnetic spectrum which correspond to peculiar colorimetric characteristics of each species.

Keywords: Spectroscopy; reflectance, spectral signature, wood veneers.
\end{abstract}

\section{Resumo}

Espectrorradiometria no visível e no infravermelho próximo de lâminas de madeiras comerciais. $\mathrm{O}$ presente estudo tem como objetivo analisar a resposta espectral na região do visível e no infravermelho próximo do espectro eletromagnético em laminas de madeiras de dez espécies florestais. As reflectâncias das amostras foram obtidas através do espectrorradiômetro Field Spec®3. Os resultados foram verificados por meio de análise de variância seguido do teste de múltiplas médias de Tukey, demonstrando existir diferenças significativas em ambas regiões do espectro eletromagnético nas espécies em estudo. As distinções de maior expressividade foram observadas na região do visível e ocorreram entre as laminas de madeira de tauari e nogueira. Essas respostas podem ser atribuídas às propriedades químicas do material investigado, bem como o teor de celulose, a proporção dos componentes presentes na parede celular e dos extrativos presentes no lume, à densidade, ângulo microfibrilar e às propriedades de resistência e rigidez. Dessa forma, a técnica empregada mostra-se como uma ferramenta capaz de registrar em regiões do espectro eletromagnético variações da reflectância que respondem à características colorimétricas peculiares de cada espécie.

Palavras-chave: Espectroscopia; reflectância; assinatura espectral; lâminas de madeira.

\section{INTRODUCTION}

The identification of forest species through wood characteristics is often difficult because many species are very similar to each other. Therefore the contribution of experts, like the "mateiros", who live in the region, or even the use of more specific investigations like the desoxyribonucleic acid (DNA) test, may be necessary. For those reasons, wood analysis is generally time consuming and it often uses destructive methods, involving various technological characteristics that can't be considered in large scale by forestry companies or in research activities (MUNIZ et al., 2012).

Many physical and mechanical characteristics have influence on wood quality, like specific mass and hardness, as well as sensory characteristics, like texture, grain, patterns, shine and color. Wood colors 
depend on quantity and types of the extractives located in the cellular walls of the core and on the chemical composition of the substances found inside the xylem, like tannins, phenols, flavonoids, stilibene, quinone and others. For those reasons, when wood is exposed to light, heat or just over time, it goes through alterations in its color (DESCH; DINWOODIE, 1993; MADY, 2000).

Techniques that prescind from the use of remote sensing science can provide nondestructive information and evaluations of an object, area or phenomena, through the analysis of data obtained from a device and without physical contact with the sample (LILLESAND; KIEFER, 1994). This may also be used as a tool to support nondestructive tests in soil analysis, pharmacology and wood analysis. The different applications of hyperspectral remote sensing techniques, where the electromagnetic spectrum is divided into several ranges, have already made possible the identification of materials in rocks and soils, of suspended sediments or algae in water cups and of biophysical variables in plants (LIANG, 2004).

Different materials can be analyzed in different ranges of the electromagnetic spectrum, where they will present specific characteristics according to the radiation range. The most used ranges are located in the visible region, where color perception occurs, between $390 \eta \mathrm{m}$ to $700 \eta \mathrm{m}$, and in the nearinfrared (NIR) region, between $700 \eta \mathrm{m}$ and $1100 \eta \mathrm{m}$.

Spectroscopy is the study of spectra, and each chemical element is characterized by a specific spectrum (MOREIRA, 2011). In physical chemistry the term spectroscopy is used to define all the techniques used for chemical and physical data acquisition through transmission, absorption or reflection of the incident radiant energy on a sample (JENSEN, 2009).

A remote sensing equipment that can perform a graphic report of the reflectance, obtained over a range of the electromagnetic spectrum, is the "spectroradiometer". It provides a curve describing the radiometric properties of a given material (PONZONI, 2007). According to Mather (2004), the typical curve of each material can be defined as the "spectral signature", and represents a standard for the identification through images of the studied objects. In literature it is also possible to find terms like "spectral response", "spectral curve" or "reflectance curve" to define this typical curve of each material. Therefore, spectroscopy techniques in visible and near infrared ranges of the electromagnetic spectrum arise in the forestry sciences as nondestructive, fast and accurate methods, able to predict the technological properties of the wood (VIANA et al., 2010).

Since the eighties the Near Infrared Spectroscopy (NIRS) has been used to estimate different wood properties. The first works that applied this technique for wood properties investigation were focused on chemical properties, like the cellulose content (BIRKETT; GAMBINO, 1988; EASTY et al., 1990; WRIGHT et al., 1990). It was also used to determine the cellulose pulp yeld (RAYMOND et al., 2001), density, microfibril angle and mechanical resistance, rapidly and with small prediction errors (SCHIMLECK et al., 2001; SCHIMLECK et al., 2001a; SCHIMLECK et al., 2002; SCHIMLECK and EVANS, 2002a; HOFFMEYER and PEDERSEN, 1995).

NIRS method is directly related to the chemical properties of the materials under investigation. Authors like Baillères et al., (2002) suggest that the prediction of wood properties, obtained from near infrared spectra, should be performed only for properties that directly depend on composition and chemical structure of the wood. However, various works have shown that other wood properties, like density, microfibril angle, together with stiffness and resistance properties, may also be predicted (THYGESEN, 1994; HOFFMEYER and PEDERSEN, 1995; ENGSTROM et al., 1998; SCHIMLECK et al., 1999; FUJIMOTO et al., 2008).

Calibration of new techniques, like the use of NIR, still depends on traditional destructive methods for the adjustment of the mathematical models, as a consequence of the quantity of forest species and of the influence of external factors that can characterize them in a peculiar way. This considered, the difficulty to create a spectral library is still related to costs, but in the meanwhile this technique presents great advantages, like the quick answers obtainable. This work has the intention to analyze the spectral behavior of ten wood veneers from ten different forest species of commercial interest, considering the visible and near infrared radiation ranges of the electromagnetic spectrum.

\section{MATERIAL AND METHODS}

Ten wood veneers from ten forest species (Figure 1), normally used in the wood industry, were used to develop this study. Each species was represented by four wood veneers, for a total of forty samples, each one measuring $15 \times 20 \mathrm{~cm}$ and $2 \mathrm{~mm}$ thick. Humidity of the samples was stable and around $12 \%$.

Processing and analysis of the samples were performed according to the following steps: 


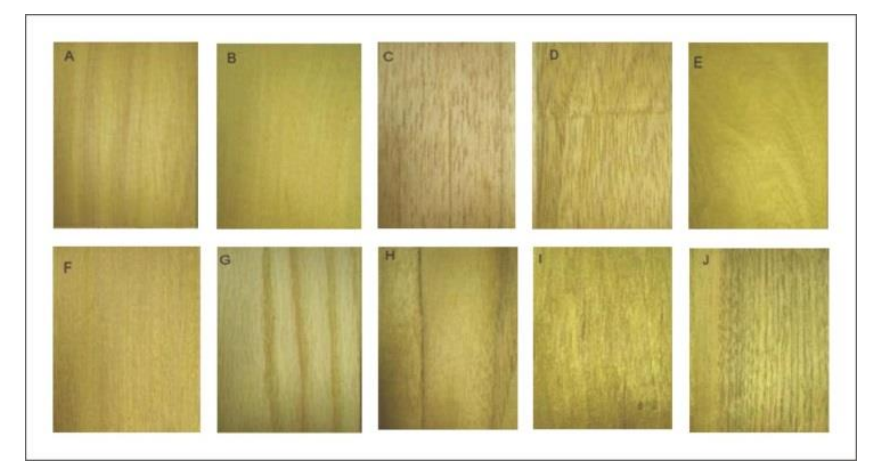

Figure 1. Woodanalyzeda: A- Tauari (Couratari oblongifolia Ducke \& R. Knuth); B- Pau-marfim (Balfourodendron riedelianum (Engler) Engler), C- Cedro (Cedrela fissilisVell.), D- Cerejeira (Amburana cearensis (Freire Allemão) A. C. Smith), E- Cabriúva (Myrocarpus frondosus M. Allemão), F- Angelim (Vatairea heteroptera Ducke), G- Carvalho (Quercus robur L.), H- Teca (Tectona grandis L. F.), I- Freijó (Cordia sagotii I. M. Johnston), J- Nogueira (Carya illinoinensis (Wangenh) C. Koch).

Figura 1. Lâminas das madeiras analisadas: A- Tauari (Couratari oblongifolia Ducke \& R. Knuth); BPau-marfim (Balfourodendron riedelianum (Engler) Engler), C- Cedro (Cedrela fissilis Vell.), D- Cerejeira (Amburana cearenses (Freire Allemão) A. C. Smith), E- Cabriúva (Myrocarpus frondosus M. Allemão), F- Angelim (Vatairea heteropteraDucke), G- Carvalho (Quercusrobur L.), H- Teca (Tectona grandis L. F.), I-Freijó (Cordia sagotii I. M. Johnston), J- Nogueira (Carya illinoinensis (Wangenh) C. Koch).

\section{Spectral reflectance readings of the wood veneers}

To obtain the spectral reflectance readings from the wood veneers, a spectroradiometer model Field Spec ${ }^{\circledR} 3$ was used, together with the connected RTZ-3ZC unit (integrator sphere) and a microcomputer. The sensor used makes measurements of the solar irradiation and radiance, and can be used both in field and in laboratory. The electromagnetic spectrum range of the instrument is from $350 \mathrm{~mm}$ to $2500 \mathrm{\eta m}$ and its spectral resolution is $10 \mathrm{\eta m}$, being able to collect up to 10 spectra per second. Readings were obtained with the spectroradiometer coupled with the RTZ-3ZC unit, after taking the reference with its Spectralon plate, a Lambertian surface, that presented a spectral reflectance of approximately $100 \%$ in the whole solar spectrum.

Lately, each wood veneer that was going to be read by the instrument was positioned on the orifice of the intergrator sphere in four different positions over the wood veneer length, obtaining four readings per sample. This procedure was repeated with four samples per each studied species. The equipment registered ten mean readings per second from each sample, distributed over its whole operative range in the electromagnetic spectrum.

\section{Conversion and processing of the spectral reflectance data}

The computational application $\mathrm{RS}^{3} 16052$ version 1 was used to process the reflectance values obtained in the previous step. This application is an user interface utilized for spectral data acquisition and storage. The application ASD ViewSpecPRO version 4.05, that allows transformation of reflectance values into the text format, necessary for further conversions, was also used. The files generated through the last application created individual spreadsheets for each reading, that were lately imported into Microsoft Office Excel 2007. In this electronic spreadsheet the elimination of possible noises, registered during the reading process, was performed. Noises (corresponding to values higher than 1) were substituted by a mean value calculated from the reflectance value of the immediately preceding and following readings.

For the statistical analysis, the values of the visible range (from $420 \mathrm{\eta m}$ to $700 \mathrm{\eta m}$ ) and of the near infrared range (from $700 \eta \mathrm{m}$ to $1100 \mathrm{\eta m}$ ) of the electromagnetic spectrum were separated. For each studied interval was then calculated the mean of sixteen readings and, basing on this value, further analysis was performed. 


\section{Statistic procedure}

This step was performed using the statistical analysis application "R" version 2.6.2 (REIS; RIBEIRO JÚNIOR, 2007). The mean of sixteen readings, taken from each species and divided into the two electromagnetic spectrum ranges, was used for the statistical procedure. Statistics applied to the means included the following steps, sequentially performed:

A Shaphiro-Wilks test was conducted, to show normality of data. This test, proposed in 1965, calculates a $W$ statistics to test if an aleatory sample with dimension $n$ belongs to a normal distribution, where small values of $W$ show deviations from normality (JOHNSON; WICHERN, 2007). Analysis of variance (ANOVA) was applied to test the hypothesis of significant differences between the means of the reflectance values for the studied species and,finally, a Tukey HSD test (Honest Significant Difference) to make multiple comparisons between the mean values of reflectance.

\section{RESULTS AND DISCUSSION}

\section{Spectral behavior in the visible region of the electromagnetic spectrum}

Results obtained through the spectroradiometric analysis were separated before going through statistical processing and will be discussed separately for the two ranges of the electromagnetic spectrum, visible and near infrared. Values for the sample measurements in the first portion of the electromagnetic spectrum are showed in table 1 .

Table 1. Analysis of variance (ANOVA) for the wood samples, in the visible region of the electromagnetic spectrum.

Tabela 1. Análise de variância (ANOVA) para as amostras de madeira, região do visível do espectro eletromagnético.

\begin{tabular}{lccccc}
\hline F.V & GL & SQ & QM & F (calculated) & Pr $(>\mathbf{F})$ \\
\hline Species & 9 & 0.38265 & 0.04252 & 24.415 & $1.879^{\mathrm{e}-11 * * *}$ \\
Residuals & 30 & 0.05224 & 0.00174 & & \\
\hline *** Significant at $0.1 \%$ level of error probability $(\mathrm{p}<0.001)$. & & &
\end{tabular}

The detection of differences in this portion of the spectrum is associated to the presence of pigments which determine the color of wood. Desch and Dinwoodie (1993) report that the colors of wood are caused by the quantity and types of extractives found in the cellular walls of the heartwood, such that when the wood is exposed to light or to heat, or even over time, its color goes through color alterations. It is possible to perceive that "nogueira" wood presented the highest coefficent of variation (Table 2) when compared to the others, and this can be explained by its heterogeneous coloration (Figure 1) that varies from brown-yellow to darkish veins. This characteristic is not observable in the wood of "pau marfim" because this one presents an homogeneous color and the consequence could be the lowest CV between the species studied in the visible region.

Table 2. Statistical parameters of samples and test comparing the means of reflectance (Tukey HSD) in the visible region of the electromagnetic spectrum for the studied wood veneers.

Tabela 2. Parâmetros estatísticos para as amostras de madeira e teste de comparação de médias de reflectância (Tukey $H S D$ ) entre as madeiras em estudo na região do visível do espectro eletromagnético.

\begin{tabular}{lcccc}
\hline Density $\left(\mathbf{k g} / \mathbf{m}^{\mathbf{3}}\right)$ & Species & $\begin{array}{l}\text { Mean Reflectance } \\
\text { (Unities) }\end{array}$ & Variance & C.V $(\boldsymbol{\%})$ \\
\hline 610 & Tauari & $0.517 \mathrm{a}$ & 0.000371 & 3.72 \\
730 & Pau-marfim & $0.504 \mathrm{ab}$ & $5.78 \mathrm{e}-06$ & 0.47 \\
440 & Cedro & $0.418 \mathrm{abc}$ & 0.001334 & 8.73 \\
510 & Cerejeira & $0.390 \mathrm{~cd}$ & 0.000105 & 2.62 \\
820 & Cabríva & $0.376 \mathrm{cde}$ & 0.005458 & 19.64 \\
590 & Angelim & $0.348 \mathrm{cdef}$ & 0.000128 & 3.25 \\
620 & Carvalho & $0.343 \mathrm{cdefg}$ & 0.006688 & 23.81 \\
550 & Teca & $0.312 \mathrm{defgh}$ & 0.000339 & 5.90 \\
540 & Freijó & $0.276 \mathrm{efghi}$ & $1.59 \mathrm{e}-05$ & 1.44 \\
610 & Nogueira & $0.170 \mathrm{j}$ & 0.002968 & 31.99 \\
\hline
\end{tabular}

* Means followed by the same letter are not different between them according to Tuckey HSD test at 5\% of significance. 
The detection of differences between the species in this portion of the electromagnetic spectrum is associated to the presence of pigments determining the color of wood (MADY, 2000). These characteristics may have influenced the higher reflectance of the "tauari" and the lower value of "nogueira", and these differences may be observed in the region A of figure 2. The spectral response curve shows the biggest differences between these two species, mainly where the spectral values are approaching the near infrared region (Figure 2, region B).

The spectral response curve (Figure 2) also shows the biggest differences for these two species, mainly as the values of spectrum closes in to the near infrared region. The "pau-marfim" wood presents spectral properties that are very similar to the ones of "tauari" (Table 3). Observing tonality and wood characteristics of "tauari" wood, whose color is light with few darker grains, almost invisible, it is easy to see similarities with the colors of "pau-marfim", although with an higher uniformity of its color that goes from light to slightly darker brown compared to the others. The mean of spectral values for "nogueira" wood is different from the others, presenting a lower spectral reflectance over the visible range of the spectrum.

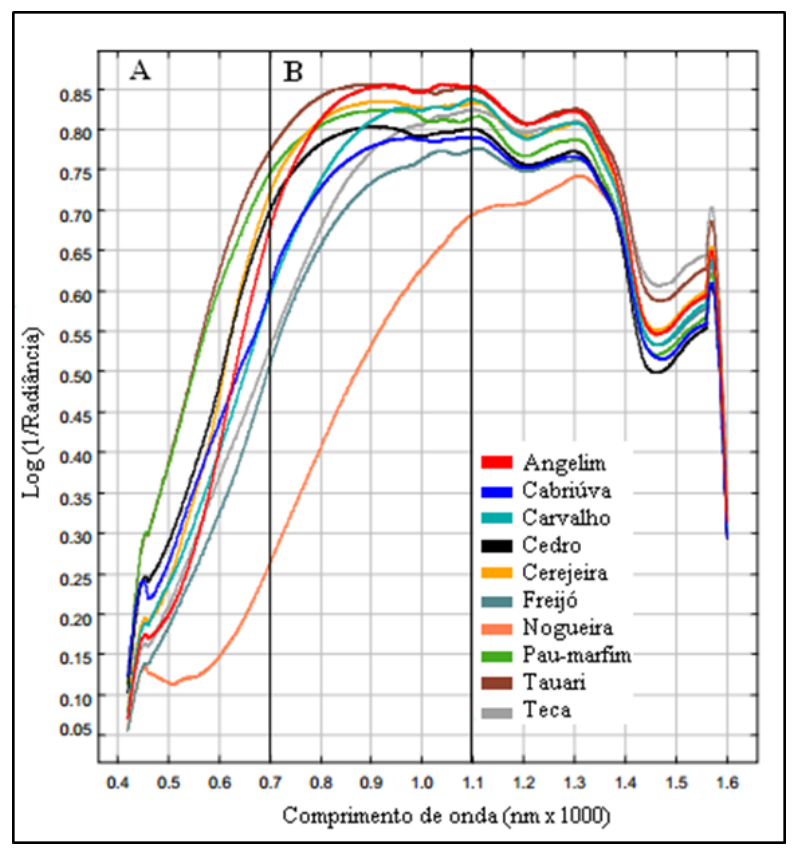

Figure 2. Spectral response curve of the wood samples in the visible and near infrared regions of the electromagnetic spectrum.

Figura 2. Curva da resposta espectral das amostras de madeiras nas regiões do visível ao infravermelho próximo do espectro eletromagnético.

\section{Spectral response in the near infrared region of the electromagnetic spectrum}

ANOVA applied to samples (Table 3) showed significant differences in the spectral reflectance of the species in this region of the spectrum too, and the same result may be verified through the Tukey $H S D$ test. In this region of the spectrum, as observable in table 4, the highest spectral reflectance is given by "tauari", and the lowest is given by "nogueira" wood.

Table 3. Analysis of variance (ANOVA) for the wood samples in the near infrared region of the electromagnetic spectrum.

Tabela 3. Análise de variância (ANOVA) para as amostras de madeira, região do infravermelho próximo do espectro eletromagnético.

\begin{tabular}{lccccc}
\hline F.V & GL & SQ & QM & F(calculated) & Pr $(>\mathbf{F})$ \\
\hline Species & 9 & 0.241037 & 0.026782 & 11.932 & $1.001^{\mathrm{e}-07 * * *}$ \\
Resíduals & 30 & 0.067334 & 0.002244 & & \\
\hline **** Significant at 0,1\% level of error probability $(\mathrm{p}<0,001)$. & & & &
\end{tabular}


Some researchers report that the spectral response in the near infrared region may be related to chemical properties of wood, like cellulose content and pulp yeld (MICHELL, 1995; SCHIMLECK et al., 2000), and for some coniferous plants, like Pinus radiata, it can be used to predict the mechanical properties of wood (THUMM; MEDER 2001; SCHIMLECK et al., 2002).

Another characteristic that may influence the near infrared reflectance, and also in the visible range, is the wood surface, because the different concentrations of pores, orientation, dimension of fibers and width of the cell wall may interfere with color and textures, giving each species their peculiar characteristics (PASTORE et al., 2011).

Table 4. Statistical analysis for wood samples and comparison test of means (Tukey HSD) in the near infrared region of the electromagnetic spectrum.

Tabela 4. Parâmetros estatísticos para as amostras de madeira e teste de comparação de médias (Tukey $H S D)$ região do infravermelho próximo do espectro eletromagnético.

\begin{tabular}{lcccc}
\hline Density $\left(\mathbf{k g} / \mathbf{m}^{\mathbf{3}}\right)$ & Species & $\begin{array}{l}\text { Mean Reflectance } \\
\text { (Unities) }\end{array}$ & Variance & C.V (\%) \\
\hline 610 & Tauari & $0.840 \mathrm{a}$ & 0.000769 & 3,30 \\
730 & Pau-marfim & $0.835 \mathrm{ab}$ & $2.18 \mathrm{e}-05$ & 0.58 \\
440 & Cedro & $0.820 \mathrm{abc}$ & 0.001015 & 4.06 \\
510 & Cerejeira & $0.807 \mathrm{abcd}$ & 0.000178 & 1.62 \\
820 & Cabríuva & 0.784 abcde & 0.000124 & 1.48 \\
590 & Angelim & 0.775 abcdef & 0.00011 & 1.25 \\
620 & Carvalho & $0.770 \mathrm{abcdefg}$ & 0.001788 & 5.45 \\
550 & Teca & 0.751 abcdefgh & 0.000606 & 3.19 \\
540 & Freijó & 0.702 defghi & $7.34 \mathrm{e}-05$ & 1.22 \\
610 & Nogueira & $0.564 \mathrm{j}$ & 0.017759 & 23.6 \\
\hline
\end{tabular}

* Means followed by the same letter are not different between them according to Tukey test at $5 \%$ of significance.

A difficulty in the use of veneers is that the orientation, radial or tangential, of the wood may not be well defined, which generates reading differences. These properties may interfere also with the scattering and absorption of different wavelengths and because of that presenting different reflectance values.

"Tauari" wood presented the highest reflectance in both spectrum regions, and there are reports that industrial processing of this wood is influenced by the presence of mineral deposits in its pores. Silica $\left(\mathrm{SiO}_{2}\right)$ is naturally present inside the elements of rays and in the axial parenchyma of the trunk as an inclusion in the lumen of the cells. (BURGER; RICHETER, 1991). Vasconcelos et al., (1993) reported that species of the genus Couratari present high silica content, at the point that the process to obtain sawn wood from trunk could be harmed, because of the abrasive effect on the cutting tools.

It is observable that the response of the species was similar in the two ranges of the electromagnetic spectrum, thus indicating that the properties responsible for coloration may also be related to the anatomical structure, and so having influence also on their reflectance. Panshin and De Zeeuw (1980) reported that the mechanical behavior of wood is not depending only on its mass but also on the proportion of the cell walls elements and on the extractives inside the lumen. This way, since there is the possibility to estimate variables through the study of the spectral curve, Hein et al., (2010) demonstrated that the chemical properties of Eucalyptus urophylla wood can be predicted through the NIRS techique.

\section{CONCLUSIONS}

- In the electromagnetic spectrum regions considered the species presented significant differences due to chemical and physical characteristics. In the visible range responses are associated to the elements that determine the veneers coloration. Responses in the near infrared region can be associated to presence of chemical components and to anatomical structures in different proportions, that are related to mechanical and anatomical characteristics.

- Basing on verification of the statistical differences between spectra of the different species, this technique demonstrates its possibility to be used for: identification of species, classification of wood 
veneers and quality control through color in the visible range of the spectrum. Spectral responses in the near infrared range may contribute to identification of species, to identification of origin of the material and could allow the characterization of veneers in quality classes based on relations with physical and mechanical properties.

- The Field Spec $₫ 3$ sensor allowed the generation of independent spectral response curves for the ten species showing that it is a tool capable to classify the wood veneers through color, with nondestructive methods, in the visible range of spectrum.

- New researches are suggested with other species, being them of commercial interest or not, and above all it is suggested that new researches should investigate the spectrum in a bigger subdivision of regions, in order to study peculiar characteristics of each species in the different ranges of the electromagnetic spectrum.

\section{REFERENCES}

BAILLÈRES, H.; DAVRIEUX, F.; HAMPICHAVANT, F. Near infrared analysis as a tool for rapid screening of some major wood characteristics in a Eucalyptus breeding program. Annals of Forest Science, Les Ulis, v. 59, p. 479 - 490, 2002.

BIRKETT, M. D.; GAMBINO, M. J. T. Potential applications for Near Infrared Spectroscopy in the pulping industry. Paper Southern Africa, v. 11, n. 12, p. 34 - 38, 1988.

BURGER, L. M.; RICHTER, H. G. Anatomia da madeira. São Paulo: Livraria Nobel S.A, 1991. 154 p.

CARVALHO, P. E. R. Espécies arbóreas brasileiras. Brasília: Embrapa Informação Tecnológica; Colombo: Embrapa Florestas, 2003. 1039 p.

DESCH, H. E.; DINWOODIE, J. M. Timber-its structure, properties and utilization. 6 ed. London: McMillan, 1993. 410 p.

EASTY, D. B.; BERBEN, S. A.; DETHOMAS, F. A.; BRIMMER, P. J. Near-infrared Spectroscopy for the analysis of wood pulp: quantifying hardwood-softwood mixtures and estimating lignin content. Tappi Journal, Atlanta, v. 73, n. 10, p. 257 - 261, 1990.

ENGSTROM, B.; JOHNSON, B.; HEDQUIST, M.; GROTHAGE, M.; SUNDSTROM, H.; ARLEBRANDT, A. Process modeling system for particleboard manufacturing, incorporating Near Infrared Spectroscopy on dried wood particles. In: EUROPEAN PANEL PRODUCTS SYMPOSIUM, 2., 1998, Llandudno, Wales. Proceedings... Llandudno, Wales, 1998. p. 107 - 114.

FUJIMOTO, T.; KURATA, Y.; MATSUMOTO, K.; TSUCHIKAWA, S. Application of near infrared spectroscopy for estimating wood mechanical properties of small clear and full length lumber specimens. Journal of Near Infrared Spectroscopy, Chichester, v. 16, p. 529 - 537, 2008.

HEIN, P. R. G.; CHAIX, G.; LIMA, J. T. Effects of sample preparation on NIR spectroscopic estimation of chemical properties of Eucalyptus urophylla S.T. Blake wood. Holzforschung, Berlin, v. 64, p. 45 - 54, 2010.

HOFFMEYER P.; PEDERSEN J. G. Evaluation of density and strength of Norway spruce by near infrared reflectance spectroscopy, Holz als Roh-und Werkstoff, Berlin, v. 53, p. 165 - 170, 1995.

JENSEN, J. R. Sensoriamento Remoto do Ambiente: uma perspectiva em recursos terrestres. Tradução José Carlos Neves Epiphanio (coordenador) ...[et al]. São José dos Campos: Parêntese, 2009. $598 \mathrm{p}$.

JOHNSON, R. A.; WICHERN, D. W. Applied Multivariate Statistical Analysis, 6 ed. New Jersey: Prentice Hall, 2007.800 p.

LIANG, S. Quantitative Remote Sensing of Land Surfaces. New York: John Wiley and Sons, Inc., 2004. $534 \mathrm{p}$.

LILLESAND, T. M.; KIEFER, R. W. Remote sensing and image interpretation. New York: John Wiley e Sons Inc., 1994.750 p.

MADY, F. T. M. Conhecendo a madeira: informações sobre 90 espécies comerciais. Manaus: SEBRAEAM, 2000. 212 p. 
MATHER, P. M. Computer processing of remotely-sensed images: an introduction. 3 ed. Chichester: John Wiley \& Sons, 2004. 324 p.

MICHELL, A. J. Pulpwood quality estimation by nearinfrared spectroscopic measurements on eucalypt woods, Journal Appita, v. 48, p. 425 - 428, 1995.

MOREIRA, M. A. Fundamentos do sensoriamento remoto e metodologias de aplicação. 4 ed. rev. e ampl. Viçosa: UFV, 2011. 422 p.

MUNIZ, G. I. B.; MAGALHÃES, W. E.; CARNEIRO, M.; VIANA, L.. Fundamentos e estado da arte da espectroscopia no infravermelho. Ciência Florestal (UFSM. Impresso), v. 22, p. 871 - 881, 2012.

PANSHIN, A. J.; DE ZEEUW, C. Textbook of wood technology. 4 ed. New York: McGraw-Hill, 1980. 722 p.

PASTORE, T. C. M.; BRAGA, J. W. B.; CORADIN, V. T. R.; MAGALHÃES, W. L. E.; OKINO, E. Y. A.; CAMARGOS, J. A. A. ; MUNIZ, G. I. B.; BRESSAN, O. A.; DAVRIEUX, F. Near infrared spectroscopy (NIRS) as a potential tool for monitoring trade of similar woods: Discrimination of true mahogany, cedar, andiroba, and curupixá. Holz forschung (Berlin. Print), v. 65, p. 73 - 80, 2011.

PONZONI, F. J.; ZULLO, J.; LAMPARELLI, R. C. Calibração absoluta de sensores orbitais: conceituação, principais procedimentos e aplicações. São José dos Campos: Parentese, 2007. 66 p.

RAYMOND, C. A.; SCHIMLECK, L. R.; MUNERI, A.; MICHEL, J. Nondestructive sampling of Eucalyptus globulus and E. nitens for wood properties: III predicted pulp yield using near infrared reflectance analysis, Wood Science e Technology, v. 35, p. 203 - 215, 2001.

REIS, G. M.; RIBEIRO JÚNIOR, J. I. Ferramentas Estatísticas Básicas da Qualidade - guia prático do R. 2007. Disponível em: <http://www.estatísticanor.xpg.com.br〉. Acesso em: 15/03/2012.

SCHIMLECK, L. R.; EVANS, R.; ILIC, J.; MATHESON, A. C. Estimation of wood stiffness of increment cores by near-infrared spectroscopy, Canadian Journal of Forest Research, v. 32, n. 1, p. 129 - 135, 2002.

SCHIMLECK, L. R.; EVANS, R. estimation of wood stiffness of increment cores by near infrared spctroscopy: the development and application of calibrations based on selected cores. IAWA Journal, V. 23, p. $217-224,2002 \mathrm{a}$.

SCHIMLECK, L. R.; EVANS, R.; ILIC, J. Application of near infrared spectroscopy to a diverse range of species demonstrating wide density and stiffness variation, IAWA Journal, v. 22, n. 4, p. 415 - 429, 2001.

SCHIMLECK, L. R.; EVANS, R.; ILIC, J. Estimation of Eucalyptus delegatensis wood properties by near infrared spectroscopy, Canadian journal of Forest research, v. 31, n. 10, p. 1671 - 1675, $2001 \mathrm{a}$.

SCHIMLECK, L. R.; MICHELL, A. J.; RAYMOND, C. A.; MUNERI, A. Estimation of basic density of Eucalyptus globulus using near-infrared spectroscopy, Canadian Journal of Forest Research, v. 29, p. 194 - 201, 1999.

SCHIMLECK, L. R.; RAYMOND, C. A.; BEADLE, C. L.; DOWNES, G. M.; KUBE, P. D.; FRENCH, J. Applications of NIR spectroscopy to forest research, Journal Appita, v. 53, p. 458 - 464, 2000.

THYGESEN, L. G. Determination of dry matter content and basic density of Norway spruce by near infrared reflectance and transmission spectroscopy, Journal of Near Infrared Spectroscopy, v. 2, p. 127 - 135, 1994.

THUMM, A.; MEDER, R. Stiffness prediction of radiata pine clearwood test pieces using near infrared spectroscopy, Journal of Near Infrared Spectroscopy, v. 9, p. 117 - 122, 2001.

VASCONCELOS, F. J.; FREITAS, J. A.; CASTRO e SILVA, A. Observações microscópicas de inclusões minerais no xilema de espécies tropicais da Amazônia, Acta Amazonica, Manaus, v. 25. n, 1, p. 55 - 68, 1993.

VIANA, L. C.; TRUGILHO, P. F.; HEIN, P. R. G.; SILVA, J. R. M. da.; LIMA, J. T. Modelos de calibração e a espectroscopia no infravermelho próximo para predição das propriedades químicas e da densidade básica da madeira de Eucalyptus, Ciência Florestal, Santa Maria, v. 20, n. 2, p. 367 - 376, 2010.

WRIGHT, J. A.; BIRKETT, M. D.; GAMBINO, M. J. T. Prediction of pulp yield and cellulose content from wood samples using Near Infrared Reflectance Spectroscopy, Tappi Journal, Atlanta, v. 73, n. 8, p. $164-166,1990$. 